\title{
Reconciling the Public, the Private and the People An Inquiry into the 'publicness' of retail urban spaces in Bengaluru
}

Prakruthi S KARADAGI, Spatial Practitioner, Urban Designer and Independent Consultant, India

\begin{abstract}
Urban public spaces are vital centres of economic activities and socio - cultural interactions. These spaces are perceived to be a property of the people as their ownership is, normally, vested with the local authorities. However, with an increasing role of private agencies, the perception of 'public' is changing, altering its nature and identity. This phenomenon is visible globally particularly in urban retail spaces such as malls and shopping centres. The manifestation of this trend is examined in Bengaluru, India. Currently, in Bengaluru, due to revenue deficits, the local authorities have turned to the private sector. Publicly owned shopping complexes are being converted to shopping malls, transitioning public spaces to Public Private Partnership (PPP) spaces. Hence, this research is an inquiry into the 'Publicness' of retail urban spaces. Three retail urban spaces with different ownerships are assessed to determine their publicness, with a focus on their agency, area, activity, arrangement and atmosphere. The primary aim of the paper is to develop and test a 'Publicness' assessment framework that can aid in formulating inclusive design approaches which facilitate a new 'Public Private People Space (PPPS)' that is vibrant, safe, accessible, sustainable and healthy for its community.
\end{abstract}

\section{Keywords}

Urban Public Space, Urban design, Public Private Partnership, Inclusive Design, Urban Planning

\section{Changing nature of urban public spaces}

\subsection{Introduction}

Urban public spaces are integral to cities. They are the loci of socio - cultural interactions and commerce. The term 'Public' intuitively conveys the idea of a common asset that is inclusive and easily accessible. This is because, historically, the ownership of urban public spaces was vested with the local authorities and it facilitated the use and appropriation of the space based on community needs. The perception that public space was, indeed the property of the public, ensured a higher level of inclusion, creating stronger bonds between the people and the place (Arendt, 1958). The $21^{\text {st }}$ century is witnessing a change in the nature of public spaces. The lines between the public and the private realm are blurring. The private sector has been actively involved in developing publicly owned spaces at the behest of urban local bodies with financial limitations (Kohn, 2004). Consequently, with an increasing role of private agencies in shaping the public realm, there is a visible change in the character and usage of these spaces. The manifestation of this trend can be observed all around the world - be it privately owned public spaces or privately operated public spaces. The research focuses on this phenomenon in retail urban spaces of Bengaluru city, India, where 
shopping activities - markets, shops, vendors, retailers, consumers - enhance the economy and vibrancy of urban public spaces.

In Bangalore, shopping complexes were built on government owned civic amenity sites ear marked to cater to the needs of the neighbourhood and providing services and facilities for the people. They were envisioned as a destination for shopping and retail activities. The rent collected from the shops was a source of income to the governing authority. In the past decade, with escalating land values and deteriorating rental collections, the local authorities have turned to the private sector. Involving the private sector has breathed life into the city's cash-strapped public sector projects. However, the change in ownership raises concerns of how inherently 'public' these spaces are and its impact on inclusion and accessibility. The Bengaluru Development Authority (BDA), a para-statal, has proposed redevelopment of 8 BDA shopping complexes into shopping malls through Public Private Partnerships (CRISIL, 2012; The Hindu, 2021). The proposal has received vehement opposition from citizens as they fear a deterioration in the quality (publicness) of these urban public spaces. The critical belief of many is that they become exclusive places, highly controlled, with distorted notions of the public realm and vulnerable user groups get excluded due to lack of affordability (Palavalli, et al., 2017). This research assesses if, rationally, there is a deterioration in the quality of the retail public spaces and if the phenomenon is indeed real, how can one improve it through design and planning solutions. Hence, this inquiry is an attempt to explore the influence of ownership on the publicness of retail urban spaces in Bengaluru and consequently, its effect on socio-economic inclusion and the built form.

\subsection{Methodology}

The aim of the paper is to formulate an empirical assessment framework that compliments the surrounding context and, interprets the 'publicness' of publicly accessible retail urban spaces beyond its ownership. The paper is divided into three sections. The first section of the paper delves into understanding theories related to the changing nature of retail urban spaces and its accessibility. The information collected through literature studies are employed to identify the parameters that determine the publicness of an urban public space. The second section examines the evolution of the retail urban public realm in Bengaluru and employs these parameters to assess three retail urban spaces with different ownerships - publicly owned, privately owned, public private partnership - to determine their 'publicness'. They are evaluated through observations, site documentation and informal surveys of user groups. The third section utilises the key findings to explore a new design narrative that hopes to integrate the architectural, urban design and urban planning framework with urban land development.

The study is limited to a design perspective of retail related urban spaces in Bengaluru. The way forward is to increase the robustness of the framework by further testing it in other contexts. While the assessment framework is tested on retail urban spaces at the moment, it indicates significant potential for adaptability to other types of public spaces.

\subsection{Theories of Public Space}

The concept of public space is multifaceted. The meaning of urban public space has evolved over the years to include the changing nature of public spaces. Jane Jacobs (1961), one of the pioneers in the discourse of public spaces, categorises public spaces in terms of intensity, permeability, mix of use and safety with her concept of 'eyes on the street'. Whyte (1980) constructs public spaces through its access and linkages, sociability, comfort and image, uses and activities. For Benn and Gaus (1984), the significant attributes for 
a public space to be distinct from its private counterparts are access, agency and interest. Access represents visual, physical and social access to the activities in it; agency pertains to the ownership and control; and interest affects the stakeholders. Jan Gehl (1996) elaborates public space activities as necessary, optional and social activities.

\begin{tabular}{|c|c|c|c|c|c|}
\hline THEORISTS & AGENCY & AREA & ACTIVITY & ARRANGEMENT & ATMOSPHERE \\
\hline $\begin{array}{l}\text { Jane Jacobs } \\
\text { (1961) }\end{array}$ & & & $\begin{array}{l}\text { Intensity and mix } \\
\text { of use }\end{array}$ & Permeability & Safe \\
\hline $\begin{array}{l}\text { William H. } \\
\text { Whyte (1980) }\end{array}$ & & & $\begin{array}{l}\text { Sociability, uses and } \\
\text { activities }\end{array}$ & Access and linkages & Comfort and image \\
\hline $\begin{array}{l}\text { Benn and Gaus } \\
\text { (1983) }\end{array}$ & $\begin{array}{l}\text { Agency-Ownership } \\
\text { and control }\end{array}$ & $\begin{array}{l}\text { Interest of } \\
\text { stakeholders }\end{array}$ & & $\begin{array}{l}\text { Visual, physical and } \\
\text { social access }\end{array}$ & \\
\hline $\begin{array}{l}\text { Kevin Lynch } \\
\text { (1984) }\end{array}$ & Control - ownership & $\begin{array}{l}\text { Fit - patterns of } \\
\text { behavior in the } \\
\text { neighbourhood }\end{array}$ & Vitality & Access & $\begin{array}{l}\text { Sense (human } \\
\text { perception and } \\
\text { cognition) }\end{array}$ \\
\hline $\begin{array}{l}\text { Carr et al } \\
\text { (1992) }\end{array}$ & & $\begin{array}{l}\text { Active and passive } \\
\text { engagement of the } \\
\text { neighbourhood }\end{array}$ & Discovery & & $\begin{array}{l}\text { Comfort and } \\
\text { relaxation }\end{array}$ \\
\hline Jan Gehl (1996) & & & $\begin{array}{l}\text { Necessary, optional } \\
\text { and social activities }\end{array}$ & & \\
\hline $\begin{array}{l}\text { Madanipour } \\
\text { (2003) }\end{array}$ & Ownership - public & $\begin{array}{l}\text { Aspirations of the } \\
\text { community }\end{array}$ & & $\begin{array}{l}\text { Distinguishable } \\
\text { form, accessible }\end{array}$ & \\
\hline $\begin{array}{l}\text { Margaret Kohn } \\
(2004)\end{array}$ & Ownership - public & & $\begin{array}{l}\text { Communication and } \\
\text { interaction }\end{array}$ & Universal access & \\
\hline $\begin{array}{l}\text { George Verna } \\
\text { and Steve } \\
\text { Teisdell (2010) }\end{array}$ & $\begin{array}{l}\text { Ownership, } \\
\text { control, Civility } \\
\text { (maintenance) }\end{array}$ & & Animation & $\begin{array}{l}\text { Physical } \\
\text { configuration }\end{array}$ & \\
\hline $\begin{array}{l}\text { Matthew } \\
\text { Carmona } \\
\text { (2015) }\end{array}$ & & $\begin{array}{l}\text { Community rights } \\
\text { and responsibility }\end{array}$ & Function & $\begin{array}{l}\text { Physical form } \\
\text { - urban design } \\
\text { innovation }\end{array}$ & $\begin{array}{l}\text { Contemporary } \\
\text { urban interface }\end{array}$ \\
\hline
\end{tabular}

Table 1. Assessment framework derived from public space theories. Source: Karadagi, P. S.

By the 2000s, the discourse on public spaces moved towards the declining quality of public spaces. Madanipour (2003) attributes the decline to financial constraints which drive local authorities to seek private investment. Kohn (2004) classifies public spaces as sites owned by the government, accessible to everyone without restrictions, fostering communication and interaction among its users (intersubjectivity). She highlights the changing nature of built forms - shopping centres changing to shopping malls - a hybrid - privately owned space that encompass characteristics of an urban public space within its architecture. Carmona et al (2008) define public space as:

'All those parts of the built and natural environment, public and private, internal and external, urban and rural, where the public have free, although not necessarily unrestricted, access. It encompasses: all the streets, squares and other rights of way, whether predominantly in residential, commercial or community/civic uses; the open spaces and parks; the open countryside; the 'public/private' spaces both internal and external where public access is welcomed - if controlled - such as private shopping centres or rail and bus stations; and the interiors of key public and civic buildings such as libraries, churches, or town halls' (Carmona, et al., 2008, p. 4) 
The Star Model for benchmarking 'publicness' of public spaces by Varna and Tiesdell (2010), designates five meta dimensions to assess a public space - ownership (public/private), control (free use), civility (maintenance), animation (activities) and physical configuration. Carmona (2015) furthers the study on public spaces by expounding on a new narrative which challenges the critical view of public spaces. He re - theorises the public space discourse by positing that public space production is place-sensitive and the design has to be constantly evolving, balanced, diverse, delineated, social, free, engaging, meaningful, comfortable and robust.

'If the dominant narrative of public space over the neoliberal era has been one of loss, wrapped up in notions of "decline" and reduced "publicness" stemming from the sorts of privatisation, commercialisation, homogenisation, exclusion and other pressures that the critiques articulate, then research demonstrates that this is certainly not the whole story, or even the dominant one. Whilst not everything is rosy in the garden, a different narrative emerges. Instead of loss, this is a narrative of renewal, one that celebrates the return of a public spaces paradigm.' (Carmona, 2015, p. 398)

The above is true in the Indian context, where public spaces have additional layers - kinetic and temporal in nature with constantly changing dynamics to accommodate social and cultural events and allowing for space appropriation (Mehrotra, 2021). Post-independence, an aspirational middle class influenced the design of public spaces based on western planning principles. This led to planners doing away with noise, large crowds, informal activities, often, at the cost of uniqueness and vibrancy visible in Indian public spaces such as bazaars (Gupta \& Gupta, 2017). This is evident in Bengaluru city where the informal sector is often excluded or displaced from the planning and design process.

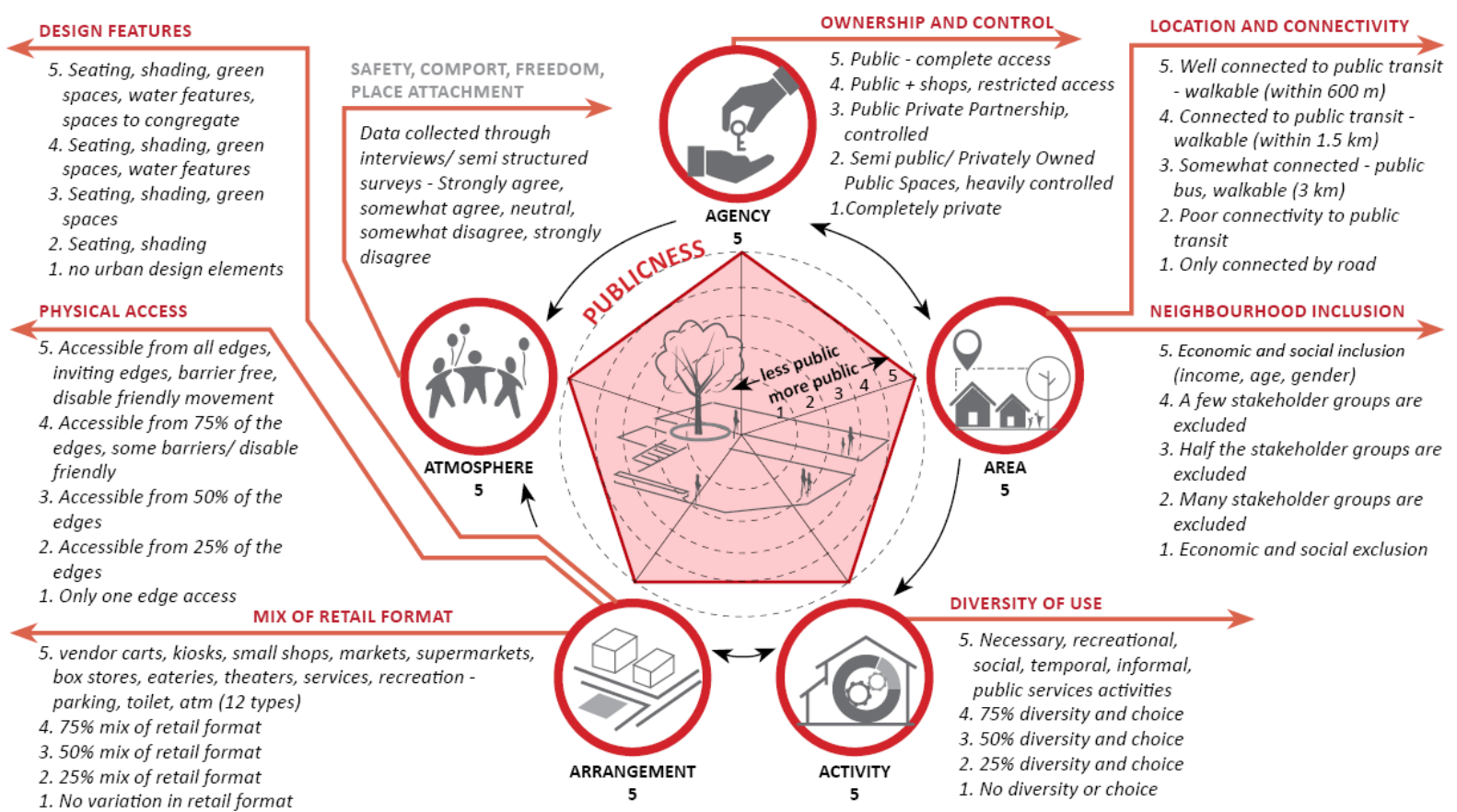

Figure 1. Assessment framework - parameters, its indicators and rating scale to determine 'publicness'. Source: Karadagi, P. S.

\subsection{Assessment framework}

The literature review of public spaces compiled in table 1, is used to derive the parameters that form the assessment framework to determine the publicness of a built urban public space. The star model of Verna is adapted to diagram the assessment. A rating scale of 5 to 1 is used to measure and diagram the 
publicness of the case studies (Refer figure 1). The term 'retail urban space' is used in this paper to compare case studies centred around retail activities with both built and unbuilt spaces which have an urban - public, semi-public - character. Each case study has distinct characteristics and typologies, ranging from informal markets, shopping centres and shopping malls.

\section{Retail urban public realm in Bengaluru}

\subsection{Bengaluru: Planning and development}

Bengaluru, the capital of Karnataka, has undergone a major transformation over the past few decades. The city has an estimated population of more than 10 million and the municipal corporation covers an area of $741 \mathrm{sq} . \mathrm{km}$. Founded in 1537 AD by Kempegowda, the city has gone from a walled medieval town to a 'global city'. Today, the city is a multi-nucleated municipal corporation with two city centres. The 'Pete' or the old city core has evolved organically over time, with mixed land use and a compact built form. The cantonment, introduced during the colonial rule - the central business district, the administrative and cultural hub - has become the face of the city. The precinct abounds with government complexes, shopping streets, museums, art galleries and shopping malls. Figure 2 presents a brief history of the evolution of Bengaluru.
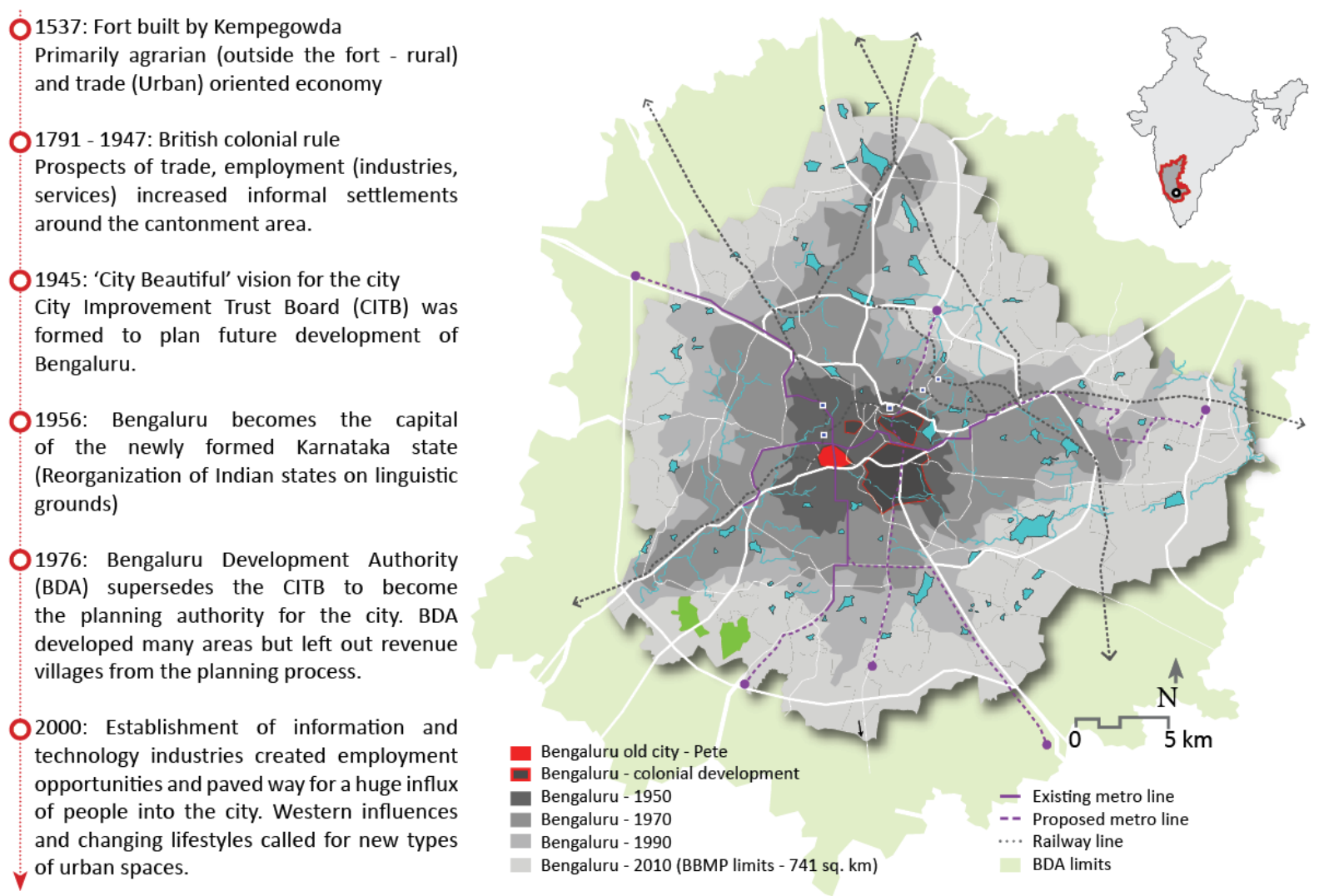

Figure 2. Evolution of Bengaluru. Source: Karadagi, P. S.

After independence (1947) several new extensions, developed by the Bengaluru Development Authority, were added to the city. Western aspirations contributed to a planning process, excluding some of the dependent communities in the new neighbourhoods. Revenue villages, such as Madiwala, located between these neighbourhoods were left out from the planning process and have developed in an unplanned manner (Ravindra, 1996; Nair, 2005). 


\subsection{Bengaluru: Evolution of retail urban spaces}

The city centres of old Bengaluru were characterised by streets with shops on the ground floor and residential quarters on the upper floors was the norm. Markets or bazaars were open and occupied streets, squares or open grounds. During the British colonial rule, the traditional bazaars were housed into built structures - KR Market (1927), Russell Market (1933) and the Johnson market (1928).

Between the 70s and 80s, the Bengaluru Development Authority built shopping complexes on civic amenity sites to cater to the surrounding neighbourhood. The Jayanagar Shopping Complex, built in 1976, was of a hybrid character, integrating the already present informal market with the new shopping centre, a super market, public offices and a cinema theatre. This was followed by BDA Complexes in other planned neighbourhoods such as Koramangala. This decade witnessed the introduction of high-rise buildings which had retail activities on the lower floors and offices in the upper floors. By the late 1980s, privately owned Alankar Plaza, Mota Arcade and Raheja Arcade brought in the beginning of a new typology of private shopping centres.
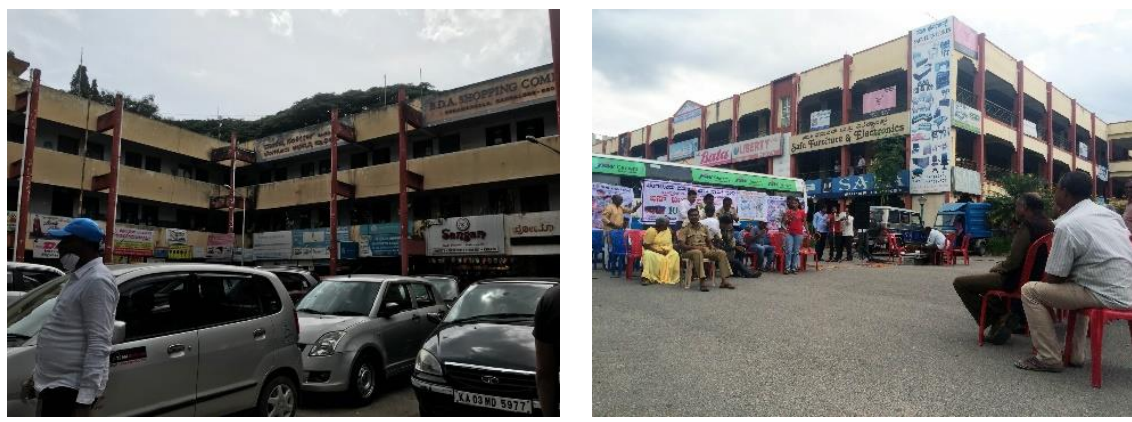

All the BDA complexes followed a similar theme: low FSI 3-story structures envoloping courtyards, orange highlights on the facade, set backs used for parking and informal activities. The complexes sometimes host neighbourhood and community meetings.

Figure 3. Koramangala BDA complex (left). Source: Karadagi, P. S. HSR BDA complex (right). Source: Citizen matters.

After the Liberalisation, Privatisation, Globalisation Policy was introduced in 1993 by the government of India, the market for the retail sector opened out with huge foreign investments pouring in. This was followed by a huge boom in the retail sector, with diverse retail formats - hyper markets, themed malls, lifestyle malls. In 2004, The Forum Mall, the first shopping mall in the city, was modelled on western design standards. The following year, the Garuda Mall in the CBD was inaugurated. The land belonged to the municipal corporation, BBMP (Bruhat Bengaluru Mahanagara Palike), and the mall and multiplex was developed under the PPP model.

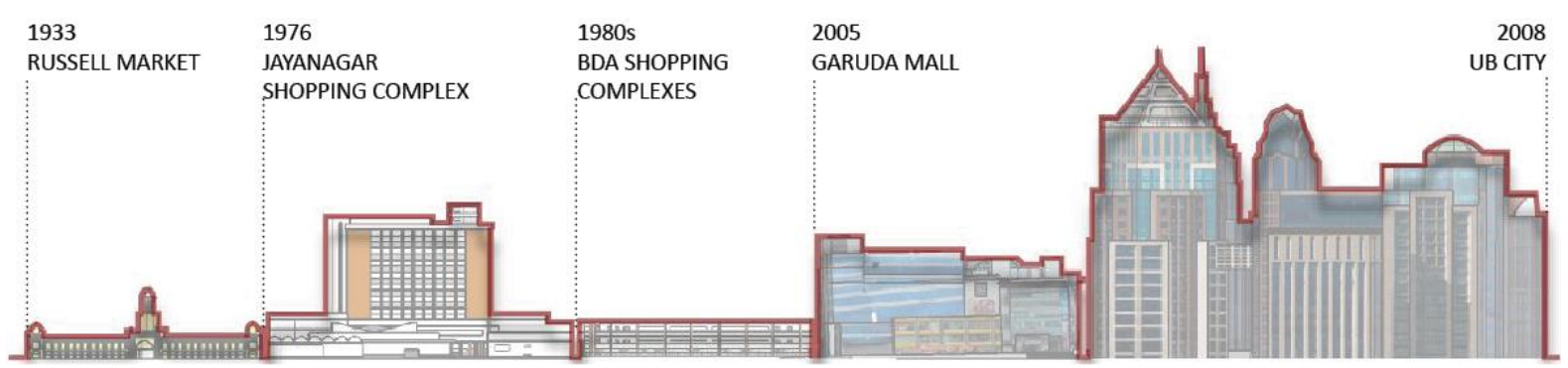

Figure 4. Evolution of built shopping spaces in Bengaluru. Source: Karadagi, P. S.

By 2010, due to revenue deficits and the inability to maintain and manage urban infrastructure, the BDA ventured to capitalise on the retail boom by leveraging civic amenity sites on which the shopping complexes are situated and redevelop them into shopping malls. With a dearth of land and increasing population, these civic amenity sites have become prime property with high real estate value. The next section scrutinises three case studies, all catering the same neighbourhood - The BDA Shopping Complex (public 
owned), the Forum Mall (private owned) and the Market Square Mall (Public Private Partnership), to assess the impact of converting BDA shopping complexes into shopping malls.

\subsection{The neighbourhood narrative}

Koramangala, a prominent residential neighbourhood in the city, was developed by the BDA in the 1970 s. It is located in south-east Bengaluru, spread over an area of approximately $7 \mathrm{sq}$. $\mathrm{km}$. It is $8 \mathrm{~km}$ away from the city centre. The layout is bounded by two major arterial roads and has an intra-city bus terminal but lacks connectivity to the metro line. The locality, initially, was not a popular choice for Bengalureans to live in as it was perceived as unsafe. The development was mostly sparse in the first two decades of its establishment. The BDA Complex in Koramangala was built in 1984, before most of the surrounding residences were constructed. A private mixed-use project, consisting of both retail outlets and office spaces, called the Raheja Arcade (1990s), is credited with changing the fabric of Koramangala (economic times). This was followed by The Forum Mall (2004), one of the earliest and successful malls in the country (Asipac, 2011). By 2005, Koramangala became a sought-after neighbourhood, a cosmopolitan hub peppered with information and technology offices, start-ups, co-working spaces, retail activities and several eateries.

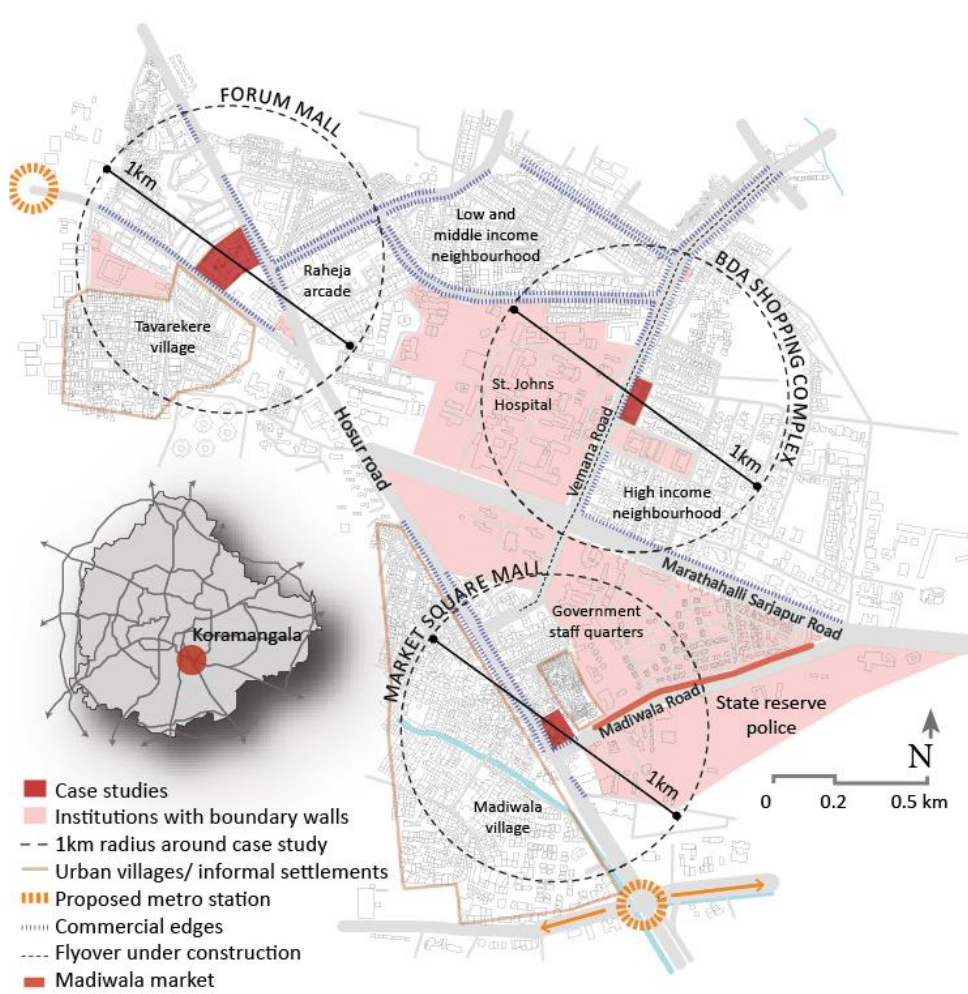

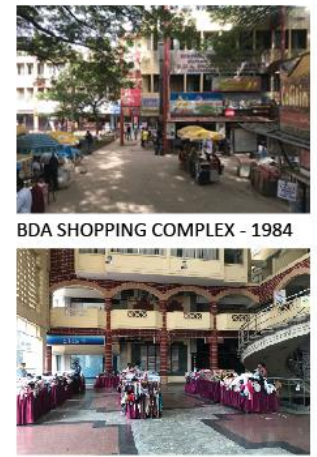
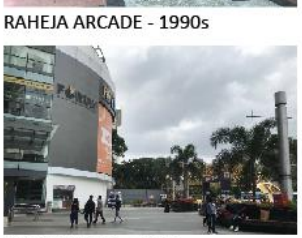

FORUM MALL - 2004

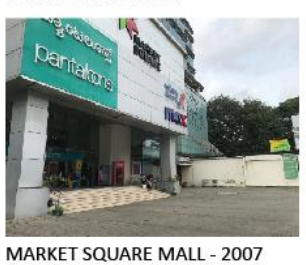

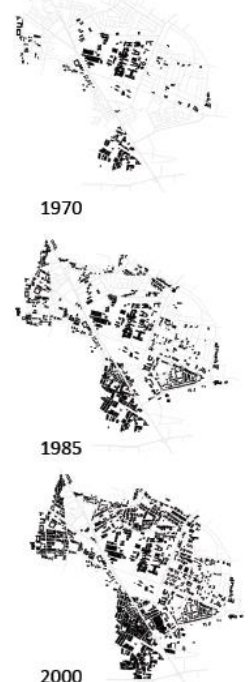

2000

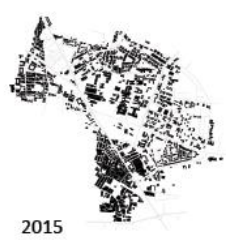

Figure 5. The neighbourhood of Koramangala. Source. Karadagi, P. S.

The Market Square Mall is located on the periphery of Koramangala, adjacent to the Madiwala urban village. This mall occupies the land where, Madiwala market, one of the oldest markets in the city, primarily selling fruits, vegetables, flowers, and was initially located. The market catered to the residents and grocery shops in Koramangala as well as the residents in Madiwala. In the late 1990s, the market land was developed with the purpose of housing the existing market. The new 6-story building did not succeed as the resultant structure did not anticipate the needs of an open informal market. The market vendors were displaced from the maidan onto the adjacent service road (of a major arterial road) and still functions as the Madiwala market. The failed building was then used as an office building. As there was no demand for office spaces close to an urban village, the building was later converted into the Market Square Mall in 
2007. This was done as a Public Private Partnership with a 30-year lease period (Build - Operate - Transfer). The revenue share was $40 \%$ of the returns to BBMP and $60 \%$ to Davanam Builders (BBMP Market Cell).

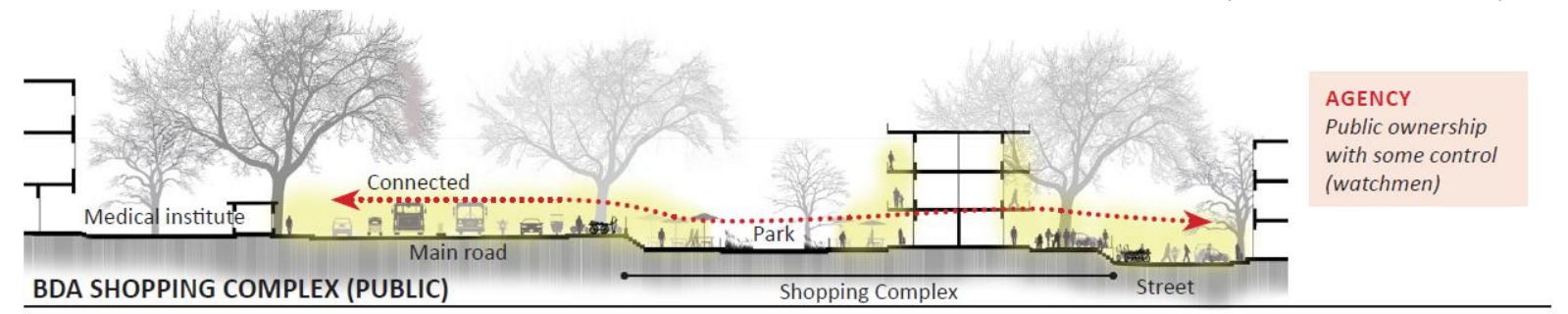
BDA SHOPPING COMPLEX (PUBLIC)
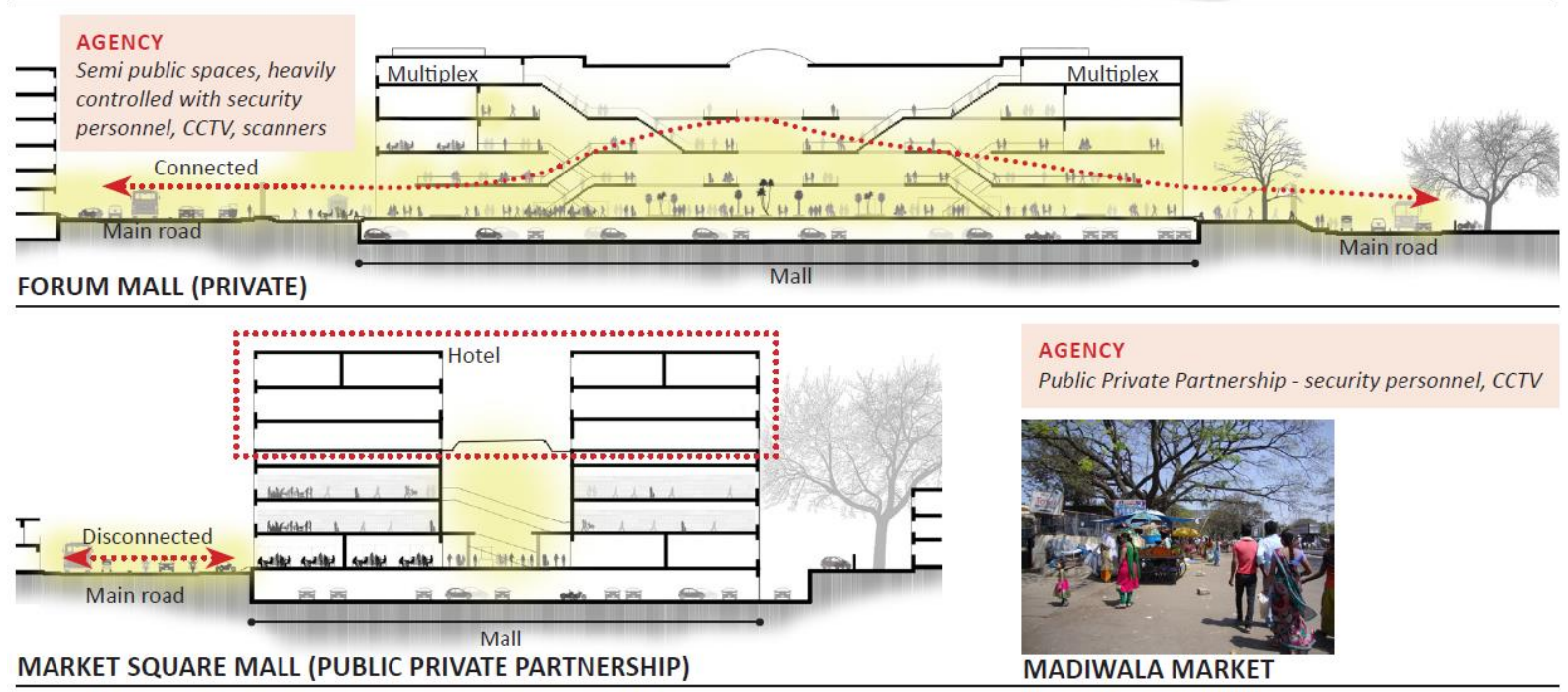

Figure 6. Sections of the three case studies. Source: Karadagi, P. S.

\subsection{Case 1: The 'public' narrative}

\section{BDA shopping complex}

The shopping complex is owned solely by the Bengaluru Development Authority and is located in the heart of Koramangala. It is surrounded by institutions on the west and south, and commercial buildings on the other two sides. Beyond the commercial buildings, the complex is surrounded by middle-income and highincome residences. From the time it was established to the year 2001, the complex saw very low footfall. As the neighbourhood gained popularity, there was a steady increase in footfall. A great number of the users visit the complex to access its public services and the ancillary services that come along with it (photocopying, notarisation). To cater to the requirements of public offices, one will find typists occupying the courtyards to help prepare documents, an unorthodox manner of space appropriation.

\subsection{Case 2: The 'private' narrative}

Forum Mall

The Forum Mall, privately owned, belongs to Prestige Group and is located between two significant and busy arterial roads in the city. A residential campus, also built by the same developers, borders the northwest of the mall. The other edges are surrounded by large commercial stores, showrooms, small shops and office spaces. While the residential neighbourhood of Koramangala is on the north-east, the south is largely flanked by the Tavarekere revenue village.

As Forum was one of the first malls in the city, people initially showed wariness to visit the mall. 15 years since its establishment, the mall has thrived and sees a huge footfall of more than 50,000 people a day (Asipac, 2011). The user groups vary - children, adults, senior citizens, men and women. The mall has, to an extent, also transcended economic boundaries and is accessed by people of different income groups. 


\subsection{Case 3: The 'Public Private Partnership' narrative}

\section{Market Square Mall}

The Market Square Mall in Madiwala is situated at the intersection of two important arterial roads in the city. The immediate surrounding of the mall comprises of government institutions such as Finger Print Bureau, State Forensic Science Laboratory, traffic police station, on the south-east; Siddharta colony - a slum like area on the north-east; repair shops, general stores, budget hotels on the west. Starting from the mall, the Madiwala market runs along the service road for a distance of about $1 \mathrm{~km}$ towards the southeast. Numerous central government staff quarters adjoin the rear of the market. Generally, people go to this mall for quick purchases or when they visit the Madiwala market.

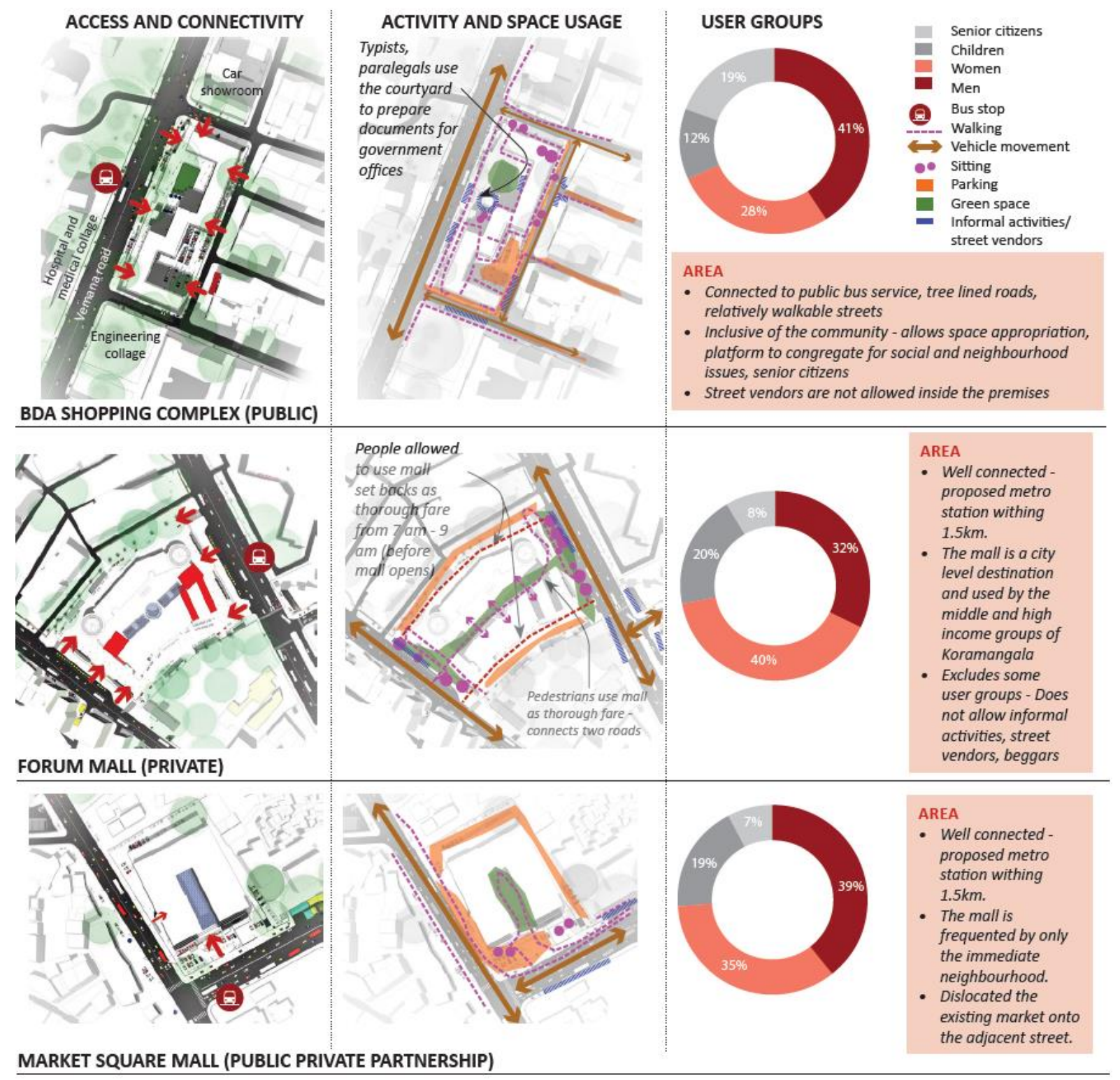

Figure 7. Access, activity and usage. Source: Karadagi, P. S. 

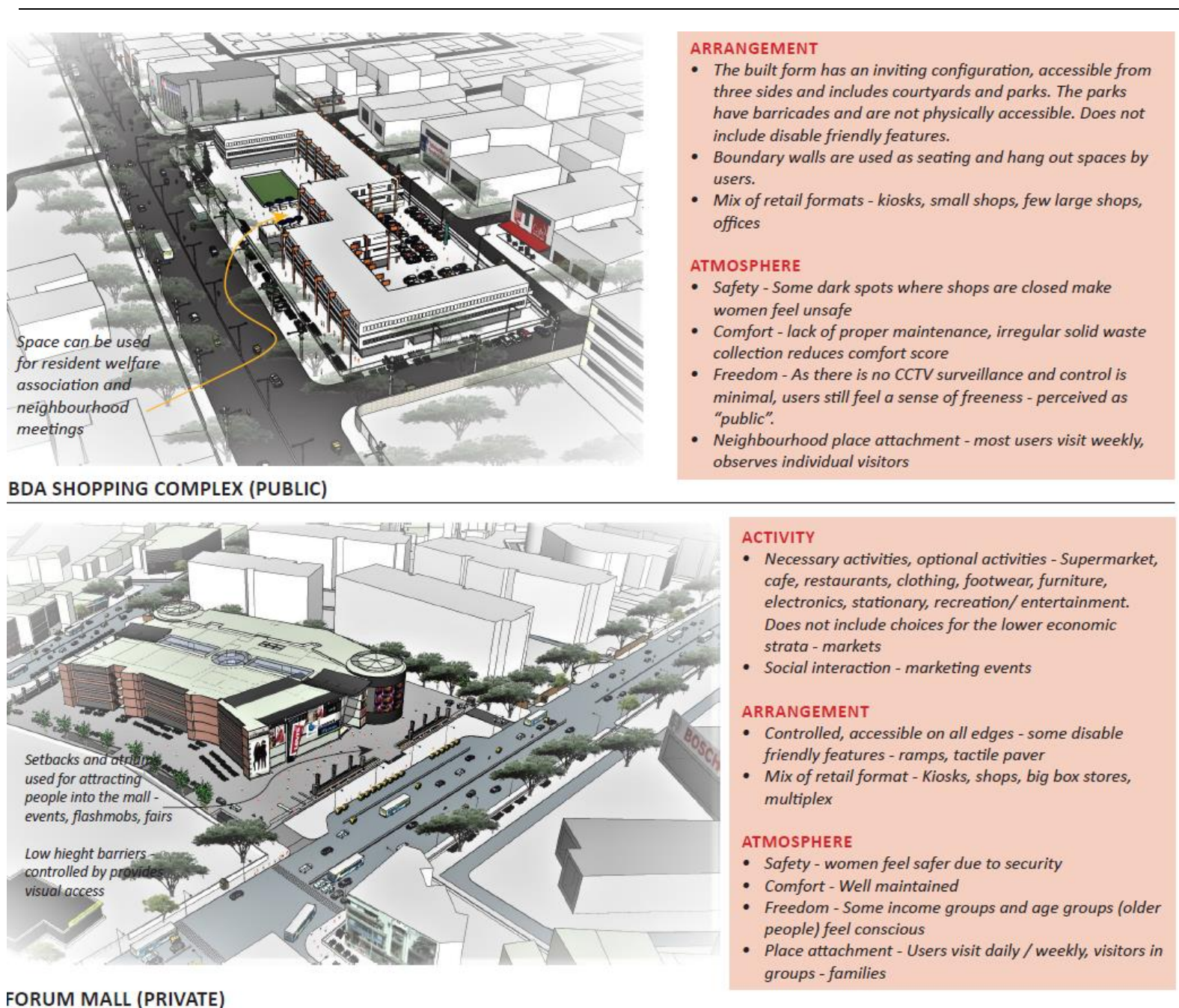

FORUM MALL (PRIVATE)

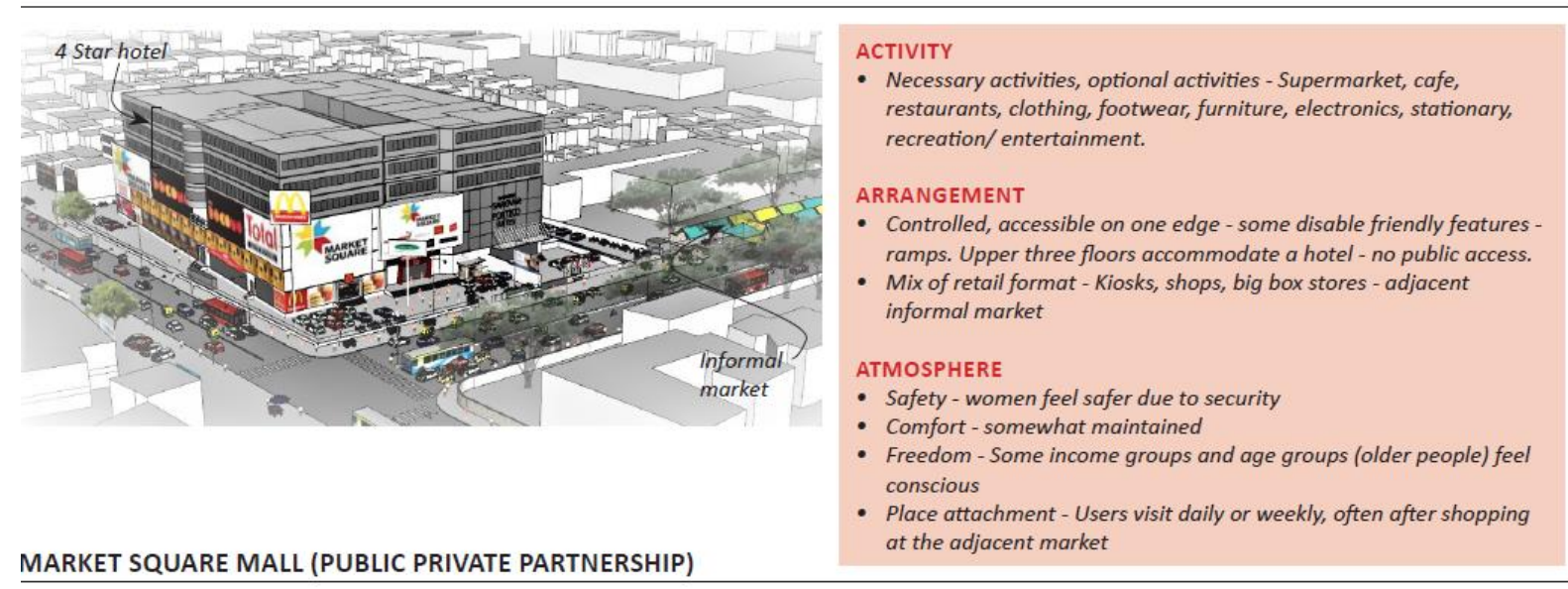

Figure 8. Arrangement - physical configuration and form. Source: Karadagi, P.S.

\section{Reconciling the Public, the Private and the People}

\subsection{Inferences}

The inferences are drawn from rating each indicator - under one of the publicness parameters - on a scale of 1 to 5 (refer figure 1 and table 3). The ratings for 'agency', 'area', 'activity' and 'arrangement', are both quantitative and empirical in nature. For example, control is assessed through the presence or absence of surveillance. Neighbourhood inclusion is observed by the presence of different user groups - based on age, 
income and gender. Physical access is assessed by the number of edges though which the user can access the space. The rating for 'atmosphere' is generated through user surveys. A structured assessment of the three case studies (refer table2 and table 3 ) illustrates that the five parameters of publicness are interrelated. The vested agency and the surrounding area (location and neighbourhood), determine the activity, its corresponding arrangement and the resulting atmosphere. These dimensions together establish the collective perception and place identity.

\begin{tabular}{|c|c|c|c|}
\hline & BDA SHOPPING COMPLEX (1984) & FORUM MALL (2004) & MARKET SQUARE MALL (2007) \\
\hline Owner & Bengaluru Development Authority & Prestige Group Limited & $\begin{array}{l}\text { Bruhat Bengaluru Mahanagara } \\
\text { Palike and Davanam Constructions } \\
\text { Private Limited }\end{array}$ \\
\hline Land area & 6020 sq. m & 16,600 sq. $m$ & 6000 sq. m \\
\hline Built up area & 6230 sq. m & 40,800 sq. m & 16,700 sq. $m$ \\
\hline $\begin{array}{l}\text { Floor Space } \\
\text { Index }\end{array}$ & 1 & 2.5 & 2.75 \\
\hline Set backs & Parking, seating for eateries & $\begin{array}{l}\text { Seating built into boundary walls, } \\
\text { temporal activities like exhibitions, } \\
\text { shows, food kiosks, to entice } \\
\text { people into the mall. }\end{array}$ & Parking \\
\hline Ground coverage & $33 \%$ & $45 \%$ & $53 \%$ \\
\hline $\begin{array}{l}\text { Open spaces, } \\
\text { social spaces }\end{array}$ & $\begin{array}{l}\text { Parks (not physically accessible), } \\
\text { courtyards }\end{array}$ & $\begin{array}{l}\text { Atriums - used for promotional } \\
\text { events, seating }\end{array}$ & Kiosks for food, accessories \\
\hline $\begin{array}{l}\text { Number of } \\
\text { stories }\end{array}$ & 3 & $5+$ Basement (parking) & $6+$ Basement (parking) \\
\hline Footfall & 5000 to 12,000 people/ day & 20000 to 55000 people/day & 3000 to 10000 people \\
\hline Ground floor & $\begin{array}{l}\text { Small shops (approx. } 10 \text { sq.m - } \\
\text { stationary shops, small eateries, } \\
\text { photocopy and printing, travel } \\
\text { agencies, cell phone and small } \\
\text { electronics stores. Small kiosks } \\
\text { - florists, magazines, utility bill } \\
\text { payment. }\end{array}$ & $\begin{array}{l}\text { Anchor stores - a well-known } \\
\text { clothing outlet, supermarkets, } \\
\text { McDonalds, KFC to draw people } \\
\text { into the mall. } \\
\text { Retail outlets (approx } 50 \text { sq. m) }\end{array}$ & $\begin{array}{l}\text { Mostly retail outlets and eateries } \\
\text { such as KFC }\end{array}$ \\
\hline First floor & $\begin{array}{l}\text { Handicraft outlets ( } 50-100 \text { sq. } \\
\text { m) and public offices such as the } \\
\text { electricity supply department and } \\
\text { regional transport office. }\end{array}$ & $\begin{array}{l}\text { Big box stores, retail outlets, } \\
\text { restaurants }\end{array}$ & Retail outlets and big box stores \\
\hline Second floor & Public offices & $\begin{array}{l}\text { Big box stores, retail outlets, } \\
\text { restaurants, food court }\end{array}$ & Super market \\
\hline Upper floors & Not present & Multiplex & $\begin{array}{l}\text { Davanam Sarovar Portico Suites, a } \\
\text { 4-star hotel }\end{array}$ \\
\hline
\end{tabular}

Table 2. Comparison between the three case studies. Source: Karadagi, P. S.

\section{Agency and surrounding area}

A comparison of the case studies reflects that just being publicly owned does not make the space vibrant and successful. Both the publicly owned and privately owned have a similar overall rating. Although the BDA complex allows for some space appropriation where spill over spaces can be used to have neighbourhood meetings, these instances are rare. The privately owned Forum Mall is rated slightly more public than the publicly owned shopping complex by virtue of its strategic location, intelligent marketing strategies and design elements. For example, allowing mall setbacks to be used as thoroughfares when the mall is closed reduces walking distance by $800 \mathrm{~m}$. PPP owned Market Square Mall is the least public as it fails to integrate the informal market into the design and restricts all public access to the uppermost levels where the 4-star hotel is located. On the contrary, privately owned and maintained Forum Mall is relatively easy to access. 


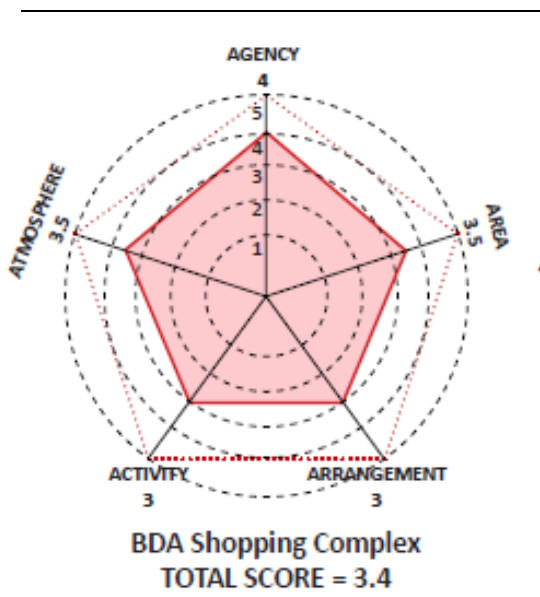

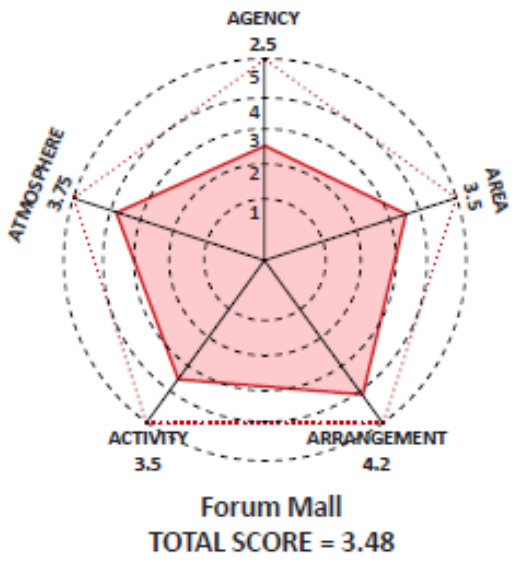

TOTAL SCORE $=3.48$

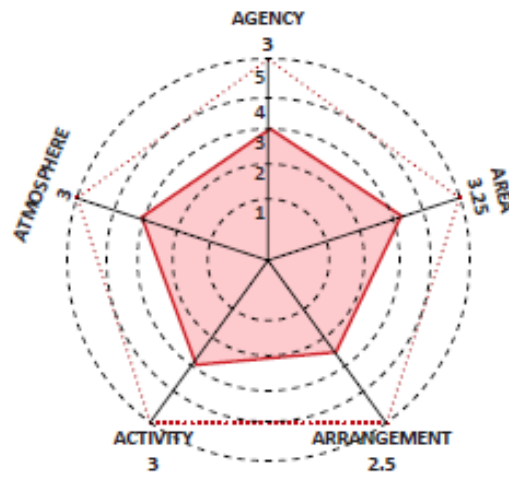

Market Square Mall TOTAL SCORE $=2.95$

\begin{tabular}{|c|c|c|c|c|}
\hline PARAMETER & INDICATOR & $\begin{array}{l}\text { BDA SHOPPING } \\
\text { COMPLEX }\end{array}$ & FORUM MALL & TOTAL MALL \\
\hline AGENCY & $\begin{array}{l}\text { Ownership and } \\
\text { control }\end{array}$ & $\begin{array}{l}4 \text { - Public + shops, } \\
\text { restricted access }\end{array}$ & $\begin{array}{l}2.5 \text { - Semi public, heavily } \\
\text { controlled but allows } \\
\text { thoroughfare }\end{array}$ & $\begin{array}{l}3 \text { - Public Private } \\
\text { Partnership, controlled }\end{array}$ \\
\hline \multirow[t]{2}{*}{ AREA } & $\begin{array}{l}\text { Location and } \\
\text { connectivity }\end{array}$ & $\begin{array}{l}3 \text { - Somewhat connected - } \\
\text { public bus, walkable }\end{array}$ & $\begin{array}{l}4 \text { - Connected to public } \\
\text { transit - walkable (within } \\
1.5 \mathrm{~km} \text { ) }\end{array}$ & $\begin{array}{l}4 \text { - Connected to public } \\
\text { transit - walkable (within } \\
1.5 \mathrm{~km} \text { ) }\end{array}$ \\
\hline & $\begin{array}{l}\text { Neighbourhood } \\
\text { inclusion }\end{array}$ & $\begin{array}{l}4 \text { - A few stakeholder } \\
\text { groups are excluded - } \\
\text { informal sector }\end{array}$ & $\begin{array}{l}3 \text { - Half the stakeholder } \\
\text { groups are excluded - } \\
\text { informal, lower income } \\
\text { groups }\end{array}$ & $\begin{array}{l}2.5 \text { - Many stakeholder } \\
\text { groups are excluded }\end{array}$ \\
\hline ACTIVITY & Diversity of use & $\begin{array}{l}3 \text { - } 50 \% \text { diversity and } \\
\text { choice - no recreational } \\
\text { activities }\end{array}$ & $\begin{array}{l}3.5-60 \% \text { diversity - no } \\
\text { informal, public services }\end{array}$ & $\begin{array}{l}3 \text { - } 50 \% \text { diversity - no } \\
\text { informal, public services }\end{array}$ \\
\hline \multirow{3}{*}{ ARRANGEMENT } & Physical access & $\begin{array}{l}4 \text { - Accessible from } 75 \% \text { of } \\
\text { the edges, some barriers/ } \\
\text { disable friendly }\end{array}$ & $\begin{array}{l}4.5 \text { - Accessible from all } \\
\text { edges, some barriers, } \\
\text { disable friendly }\end{array}$ & $\begin{array}{l}2 \text { - access from one edge, } \\
\text { partial access from the } \\
\text { other }\end{array}$ \\
\hline & $\begin{array}{l}\text { Mix of retail } \\
\text { format }\end{array}$ & $\begin{array}{l}2-25 \% \text { mix of retail format } \\
\text { - small shops, eateries, } \\
\text { public offices, some big } \\
\text { stores }\end{array}$ & $\begin{array}{l}3.5-60 \% \text { mix of retail } \\
\text { format - no informal } \\
\text { activities, space provided } \\
\text { for temporal activity }\end{array}$ & $\begin{array}{l}3.5 \text { - } 60 \% \text { mix of retail } \\
\text { format - adjecent informal } \\
\text { market provides choice, } \\
\text { affordable }\end{array}$ \\
\hline & Design features & $\begin{array}{l}3 \text { - Seating, Green spaces, } \\
\text { informal spaces }\end{array}$ & $\begin{array}{l}4.5 \text { - Seating, shading, } \\
\text { green spaces, water } \\
\text { features }\end{array}$ & 2 - steps used for seating \\
\hline \multirow{4}{*}{$\begin{array}{l}\text { ATMOSPHERE } \\
\text { (data collected } \\
\text { through } \\
\text { surveying } \\
\text { different users } \\
\text { - age, gender, } \\
\text { vendors) }\end{array}$} & Safety & 3 - Neutral & 4 - Somewhat agree & 3 - Neutral \\
\hline & Comfort & 3 - Neutral & 4 - Somewhat agree & 3 - Neutral \\
\hline & Freedom & 4 - Somewhat agree & 3 - Neutral & 3 - Neutral \\
\hline & Place attachment & $\begin{array}{l}4 \text { - Users visit weekly/ bi } \\
\text { weekly }\end{array}$ & 4 - Users visit weekly & 3 - Users visit bi weekly \\
\hline
\end{tabular}

Table 3. Assessment of 'Publicness'. Source: Karadagi, P. S.

\section{Activity and arrangement}

A high diversity in activities and retail format draws in people who in turn attract more people (Whyte, 1980). This enhances natural surveillance - eyes on the street (Jacobs, 1961) - and creates a sense of safety for vulnerable user groups such as women and children. The BDA complex include mostly, public services and necessary activities. The Forum Mall includes necessary, recreational and social activities but does not provide public services. The Market Square Mall lacks recreational, social activities and public services and barely sees any footfall on weekdays. 
Layers of necessary, optional and social activities - arranged in a hierarchy of retail formats and spaces; vendor carts, kiosks, small shops, big box stores peppered with cafes, open spaces, recreational spaces; will attract more user groups. Pricing and affordability also play a key role in including vulnerable user groups and contribute to their sense of comfort and place attachment. The type of retail format defines pricing, and, hence determining socio economic access. For example, it was observed that lower income groups feel more comfortable buying from small shops and street vendors. Street vendors occupy the pedestrian walkways outside both Forum Mall and the BDA complex, increasing natural surveillance and indirectly boosting the livelihood of these vendors. As there is a kilometre long market right next to the Market Square Mall, not many street vendors are present on the pavement adjoining the mall.

Additionally, it was observed that high permeability - ease of access, entry points, thresholds and other urban design elements like seating, trees, shading facilitate social activities such as meeting people, people watching, events, engage the users with the urban space. The boundary walls of the BDA complex are used as seating; Forum has formal seating spaces built into the boundary walls; Market Square does not have any seating spaces but the steps at the entry is used for sitting. Hence, incorporating flexible spaces for sitting, resting, informal markets, street vendors, in the design will increase social inclusion. Similarly, reducing barriers and control devices such as tall boundary walls and fencing, enables both physical and visual access, drawing people into the space and enhancing its vibrancy.

Inside and outside was also an important factor of distinction. Though anything outdoors and open was considered to be more public, movement though built spaces, their access, types of activities, and opportunities of interaction were important factors irrespective of public or private ownership. Legibility of the form, proximity and facilities like parking, escalators also influence people's choices, behaviour and sense of comfort.

\section{Atmosphere}

Atmosphere was assessed mainly through semi structured surveys and informal interviews with stakeholders - consumers, sellers, management. Respondents associated place attachment with activities and spaces that are part of their life. Presence of other people, opportunities for formal and informal interaction, create a sense of publicness. Even though Forum has heavy surveillance, some user groups such as women perceive it to be safer as they are not exposed to eve teasing. Many users find the Forum Mall more comfortable as it is well maintained. The Market Square Mall was rated cleaner than the BDA complex but respondents feel it does not maintain expected standards. The street vendors fell the freedom to park their carts on the pavement outside but are not allowed inside any of the three case study premises. In other words, what is perceived as 'public' by some groups of people may not be perceived the same way by others.

Assessing the three case studies reveals that public spaces must have diversity and choice. A hierarchy of activities and flexible spaces will attract users. Design, aimed at inviting people in (rather than control their movement), will enhance social inclusion, footfall and vibrancy.

\subsection{A new design narrative}

Public spaces are critical to the process of urban design and urban planning. Design practices have to move beyond a 'one size fits all' approach to a place-sensitive and multidimensional approach that respects the heterogeneity of human perception and everyday activities. Reinventing public space design within the formal framework of political and social ideologies and morphological typologies, offers challenging yet exciting opportunities for making adaptive public places. Designing from the users' perspective, empowers the stakeholders to define, construct, and control publicness through their actions, reactions, and interactions.

\section{L isocarp}


The assessment framework and the resulting 'publicness' diagram, includes the surrounding area and neighbourhood into the process of design and planning, acting as a useful tool in public place production. The framework enables the integration of urban design and urban planning with land development and real estate to bridge the gap between the 'providers' and 'users' of public space and can be used by anyone - users, sector experts, authorities - to assess publicness. This research hopes to add to the discourse of drafting design codes and regulations - which facilitate universal access and provide a plethora of choices through new typologies of public spaces.

\subsection{Conclusion}

Public spaces are crucial to cities and set the stage for social interaction, events and memories. Essence of the public realm is constituted by this dialectic process of interaction, where the boundaries of publicness are constantly interpreted, restructured, and reconstructed through the forces of formal and informal control-individual, interactive, and institutional. It is essential to connect the new age hybrid public spaces with its urban fabric, inducing a hierarchy of diverse activities and spaces to encourage access to user groups of all classes, women, children, senior citizens and the informal sector, and aim towards creating more inclusive and yet successful urban spaces for the people, integrating the community with civic amenity sites through urban design and planning principles. This will enable a design approach that reconciles the 'Public' and the 'Private' space with its people and facilitates a new hybrid - 'Public Private People Space'. Additionally, augmenting the design approaches with sound government policies is essential to create safe, vibrant, inclusive neighbourhood public spaces and streets, accessible to people from all walks of life.

\section{References}

Arendt, Hannah (1958) The Human Condition, Chicago: University of Chicago.

Asipac. (2011) 'Demand \& supply of mall space in Bangalore', 1 November [online]. Available at: http://www.asipac.com/uploaded/pdfFiles/1326356416Asipac_Study Mall_Demand_Supply_ in_Bangalore_Nov_2011.pdf (Accessed: 20 January 2015)

Banerjee, T. (2001) 'The future of public space: Beyond invented streets and reinvented spaces'. Journal of the American planning association, 67, p9-24.

Ben, S. I. and Gaus, G. F. (1983) Public and private in social life. New York: St Martin's Press.

Carmona, M. (2015) 'Re-theorising contemporary public space: A new narrative and a new normative', Journal of urbanism: International research on placemaking and urban sustainability, 8:4, p373405.

Carmona, M., de Magalhães, C., \& Hammond, L. (2008) Public space: The management dimension. New York \& London: Routledge.

Carr, S., Francis, M., Rivlin, L. G., \& Stone, A. (1992) Public space. Cambridge: Cambridge University Press.

CRISIL. (2012) Redevelopment of BDA complex at Indiranagar. Bengaluru: Bengaluru Development Authority.

Gehl, J. (1996) Public spaces \& public life. Copenhagen: Kunstakademiets forlag.

Gehl, J., \& Svarre, B. (2013) How to study public life: Methods in urban design. Washington D.C.: Island Press.

Gupta, A., \& Gupta, A. (2017) Celebrating public spaces of India. New Delhi: Grantha Corporation. 
Jacobs, J. (1961) The death and life of great American cities. New York: Vintage books.

Kohn, M. (2004) Brave new neighbourhoods: The privatization of public space. New York and London: Routeledge.

Lynch, K. (1984) A theory of good city form. Cambridge: The MIT Press.

Madanipour, A. (2003) Public and private spaces of the city. London and New York: Routledge.

Mehrotra, R. (2021) The kinetic city \& other essays. Berlin: ArchiTangle.

Murthy, R. S. (2012) 'Chaos, bedlam unabated on HSR 27th main road', Citizen Matters (monthly edition), 5 February [online]. Available at: https://bengaluru.citizenmatters.in/3814-chaos-bedlamunabated -on-hsr-27th-main-3814 (Accessed: 3 January 2015)

Nair, J. (2005) The promise of the metropolis: Bangalore's twentieth century. New Delhi: Oxford University Press.

Palavalli, B. M., Srinivas, B., \& S., S. (2017) Bengaluru's continuing inequity: An eviction impact assessment of Ejipura/Koramangala four years after its demolition. New Delhi: Housing and land rights network.

Ravindra, A., (1996) Urban land policy: Study of metropolitan city. New Delhi: Concept publishing company

The Hindu. (2021) 'BDA complex redevelopment plan back on the cards?', 8 July [online]. Available at: https://www.thehindu.com/news/cities/bangalore/bda-complex-redevelopment-plan-back-onthe-cards/article35204150.ece (Accessed: 30 August 30 2021)

Varna, G., \& Tiesdell, S. (2010) Assessing the publicness of public space: The star model of publicness. Journal of urban design, 15(4), p575-598.

Whyte, W. H. (1980) The social life of small urban places. New York: Project for public spaces. 